\title{
Indigenous resurgence, anthropological theory, and the cunning of history
}

\author{
Terence Turner
}

\begin{abstract}
Why has the recent period of global centralization of capital, from the 1970s to the present, also been a period of resurgence of indigenous movements and of forms of global civil society that have supported indigenous rights? This article argues that tackling this question can only be done by using concepts that emphasize what Hegel called the 'cunning' of history: the fact that the same historical process can on the one hand bring devastation to indigenous habitats and on the other hand create opportunities for political leverage by indigenous societies to gain recognition of the legitimacy of their different social, cultural, and economic systems within their ambient nation-states. Politically engaged anthropological theory, it seems, needs concepts that emphasize these contradictionswhich in a nutshell means more Marx and less Foucault.
\end{abstract}

Keywords: activism, cunning of history, 'globalization', historical context, indigenous resurgence

Particularly in the field of indigenous studies, anthropological theory has become a vital political issue. ${ }^{1}$ I want to make two points here. First, that in order to appreciate and support particular indigenous people's struggles, it is crucial to understand these particular struggles as part of a global phenomenon. And second, that anthropological theory can only make sense of this global indigenous resurgence through concepts that stress the contradictions and lacunae of shifts in the global and state system in the last quarter of the twentieth century, which indigenous people have courageously managed to exploit.

My reflections here on this issue were triggered by my role as commentator in the session
"Envisioning history: Anthropological theory and the rights of indigenous people" at the Canadian Association for Social and Cultural Anthropology conference in Montreal in May 2006. The session was devoted to examining the ways anthropological theories have affected struggles for indigenous peoples' rights. The authors of the session's papers mostly belonged to a group led by Professor Michael Asch of the University of Victoria and all of them have been working with Canadian hunting and foraging societies. Michael Asch's group has made itself a major force for the defense of the rights of Canadian First Nations and many of its members have been involved as expert witnesses in Canadian court 
proceedings dealing with indigenous land rights and cultural rights issues. In their court testimony, they have often had to contend with opponents of First Nations' land and cultural rights, who base their cases on anthropological theories, mostly of evolutionistic or cultural materialist types. The authors were concerned, as activists, to bring out the political issues that arise from the political resurgence of indigenous people, but also, as anthropologists, with its significance for anthropology and vice versa, that is, the part played by anthropological theory, sometimes by supporting it or more often by indirectly seeking to delay it by legitimizing attempts by the Canadian and US governments to strip indigenous peoples of their lands and resources, while formulating reductionist theories that misrepresent their cultures and modes of livelihood, and denying their agency as social actors. For Asch and his students, including the organizer of the session Marc Pinkoski, theoretical critique has become a vital practical and political issue, rather than merely an academic exercise (for an earlier exposé of their argument see Pinkoski and Asch 2004).

I was invited to act as commentator on the session because although my anthropological research has been with indigenous societies in the Brazilian and Venezuelan Amazon (see Turner 1993, 1996, 2000; Turner and Fajans-Turner 2006), as an activist I have faced similar issues concerning the relation between anthropological theory and professional responsibilities and the struggle to defend the territorial and cultural rights of the peoples with whom I have worked (see Turner 1999b). I have also been concerned with more general issues of globalization's impact on indigenous movements and rights, both in my own writings and as a member of the Committee for Human Rights of the American Anthropological Association. My role as commentator at the Montreal session was thus to try to put the activist interventions and critical theoretical reflections of my Canadian colleagues into a broader comparative perspective.

The Canadian cases presented local manifestations of a global phenomenon of great historical, anthropological, and human significance: the continued economic viability, cultural continuity, demographic growth, and political resurgence of indigenous peoples or First Nations around the world. While the presenters only discussed hunting and foraging peoples, these being the groups among whom they conducted their own field research, its is important to bear in mind that hunters and foragers account for only a small proportion of indigenous peopleswho share most of the same problems and issues-worldwide. Also the theoretical concepts employed by the presenters to "envision" the history of anthropological theory and indigenous rights struggles, need themselves to be understood, just as the facts and cases they describe, in the wider global and historical contexts that produced them. Theoretical concepts such as 'colonialism' and 'post-colonialism', 'nation', 'globalization' and 'governmentality' either originated or have significantly changed in meaning during the same historical period as the resurgence of indigenous peoples (roughly from 1970 to the present), and responded to many of the same historical factors (see also Turner 1999a, 2002, 2003, 2004). These factors, I would argue, appear in some cases to be changing again, with historical and theoretical consequences that are of great significance.

In the following section I attempt to summarize my ideas about the global political-economic forces that have enabled indigenous peoples all over the world to launch effective struggles for their rights and territories, and to indicate some of the implications of these dynamics and movements for anthropological, and more broadly social theory.

\section{The historical context of the indigenous resurgence}

Following the collapse in the early 1970s of the Bretton Woods arrangements,- - designed at the end of World War II to enable states to control transnational corporate and finance capital and support currency convertibility, the accelerated global centralization of capital, especially finance capital—has forced states to defend the stability of 
their currencies by curtailing inflationary spending on domestic social programs. This meant retreating from the 'class compromise' of the welfare state-the social-democratic attempt by the Western democracies to promote relative class equality of all citizens that gained political ascendancy during and following World War II. It is important to recognize that this commitment to social and political homogenization was accompanied by the persistence of assimilationist policies toward racial, cultural, and indigenous minorities (with some moderate exceptions such as John Collier's tenure as Director of the Bureau of Indian Affairs in the Roosevelt administration in the US). The retreat from welfare-state policies in the early 1970s also led to the abandonment, for practical purposes, of the nationalist ideological and cultural project of assimilating economically and culturally marginal minorities, above all indigenous groups into the 'nation', conceived as the ethnically and culturally homogeneous population of the state. The same political-economic developments caused the reversal of the class dynamics of the post-World War II period, characterized by the progressive expansion of the middle class, by promoting the differentiation from the rest of the middle class of a new upper class of super-wealthy with close financial ties to the global economy. The political and ideological effects of this shift in class dynamics were reinforced by the diminution of states' control over their monetary and social policies - the result of the achievement of emancipation of state control by transnational capital in the 1970s and 1980s.

This was a significant diminution of the political powers of states, and thus the ability of their internal systems of electoral politics to exercise meaningful influence over these aspects of economic and social life. States remained important, indeed indispensable, as the executors of the economic and administrative policies required by global capital and financial markets, but they lost their autonomous character as the highest-level economic and political units of the world system, just as they lost their social and ideological character as integral nations, capable of assimilating their constituent classes and ethnic minorities into internally united and politically uniform societies.

These transformations of the social, politicaleconomic, and ideological character of states brought fundamental changes in the cosmological space-time of Western civilization-changes that have affected the situation and prospects of the indigenous peoples located within those states. The Modern conception of social time as a unilinear diachronic progress culminating in the development of internally homogeneous nation-states rather rapidly gave way to a nondirectional, decentered notion of synchronic pluralism, where states serve as frames guaranteeing the coexistence of socially and culturally different sub-groups; in other words, to postmodern multiculturalism. The key role of the state in this new cosmological configuration is not to impose and maintain internal uniformity among its members as bearers of a common national identity, but to maintain the external uniformity of their economic activities as workers, consumers, managers, and capitalists - that is, as good members of the uniform global economy. In this way, the commitment to jural and administrative equality remains the touchstone of the political-economic functions and ideological legitimacy of states, but the application of this principle has become severed from any considerations of assimilation to a national ethnic identity, or for that matter from any beyond the minimal considerations of provision of social welfare or economic support.

There is, however, an ironic sense in which ethnic, racial, or cultural difference remains strategically relevant in the new system of synchronic pluralism. Fully assimilated members of the dominant society of a state can claim no special treatment from their governments based on the latter's commitment to the equal treatment of differences, because they lack difference in any relevant sense. By emphasizing the very differences that previously stigmatized them as not sufficiently evolué, obviously unassimilated indigenous persons or groups may now find themselves able to demand recognition, rights, and protections from states previously reluctant to grant them. This point can be put another way 
by saying that egalitarianism remains a basic principle of state ideologies, but it has reversed its meaning in a fundamental respect. It is no longer an equality of ideally homogeneous identities (as of citizens assimilated to a uniform national norm) but an identity of differences, where contrastive identities become the basis for legitimizing the equality of claims on the state.

Multiculturalism and the principle that cultural difference confers a right to formal political and social equality have in this way become essential to the legitimation of states in the age of globalization. The very economic and political processes that threaten to undermine the legitimacy of states in their roles as implementers of the global capitalist system, and oblige them to abandon programs for the promotion of social and economic equality, also put pressure on them to recognize and defend the equal rights of groups whose cultural and social differences from the hegemonic national norm until recently served as stigmata of inequality. This ideological principle of the right of difference, I have argued, cannot be understood in its own terms simply as the outcome of enlightened legal reasoning or progressive political theory, or as the spontaneous product of indigenous peoples and other distinctive cultural groups by themselves, but as the ideological expression of the effect of the operation of the global capitalist system on the internal social dynamics and class structure of individual nation-states. Its grounding in the global economic system is the real basis of the expansion of civil society in the recent age of globalization from the internal societies of nation-states to what has come to be called 'global civil society'.

While they have had many unfortunate political and social effects, such as the despoliation of environmental resources and indigenous habitats in the intensified race to extract energy and raw materials, the transnational centralization of capital —or what has been called 'globalization', and the neo-liberal social and economic policies it has brought in its train-have also, by a process akin to what Hegel (1953) called the 'cunning' of history, helped to create opportunities for political leverage by indige- nous societies to gain recognition within their ambient nation-states of the legitimacy and viability of their different social, cultural and economic systems - ways of using their territories and other material resources. It is a tribute to the resilience, courage, and political perspicacity of so many indigenous groups that they have been able to exploit the opportunities provided by these contradictory developments of the global political economy as mediated through their ambient nation-states, even as they deal with the negative effects of the shrinkage of social services and threats to their territorial and resource bases from those same states.

\section{More Marx, less Foucault}

What does all this imply for anthropological theory? I would argue that it implies concepts like 'colonialism' or Foucault's 'governmentality' are inadequate and even potentially misleading if employed as theoretical frameworks for understanding the contemporary situation of many indigenous peoples, whether hunterforagers, swidden horticulturists, pastoral nomads, or Central American maize farmers. These rubrics seriously distort current political and economic reality by assuming that they are essentially the products of deliberate policies by states or else by capitalist corporations, without attempting to analyze the political-economic system of which those states and corporations form parts. By exclusively emphasizing the oppressive aspects of the imposition of state power on subject populations, they miss the importance of contradictions and lacunae in the contemporary global and state system in creating opportunities for indigenous peoples to assert and defend their cultural differences and rights to resources. They also ignore the reality of the agency and capacity for effective political action and cultural transformation of indigenous groups that have enabled them to act successfully in their historical situation. They thus fail to deal with the great question of why the recent period of global centralization of capital (1970 to the present) has also been a period of resurgence of indigenous 
movements for territorial rights and cultural autonomy, and why the same period has given rise to forms of global civil society that have supported indigenous rights and (however ambivalently) environmental stewardship.

So I would say that we need more Marx and less Foucault. Above all, we should avoid theoretical formulations, like 'post-coloniality' or Foucault's 'governmentality' and its immediate ancestors, such as 'discourses of power', or some forms of world system theory, that in effect uncritically continue the work of capitalist and imperialist domination of indigenous and other non-Western cultures by postulating that the former are invariably and totally effective in subverting, controlling, and inauthenticating the latter, along with any possibility for open and effective organized resistance by movements of national populations. Indigenous peoples, by their courageous and effective struggles in Canada and all over the world, have been demonstrating the inadequacy of these forms of theoretical colonialism, and creating by their actions a reality that challenges the trendy forms of irrealism our discipline has been toying with while they have been fighting for their collective social and cultural lives.

Terence Turner (PhD from Harvard, 1965) has worked for decades with indigenous peoples of the Brazilian Amazon, mostly the Kayapo, but recently also the Yanomami. He is involved in advocacy and human rights work and is interested in indigenous peoples' political struggles and associated ecological, cultural, and rights issues. His theoretical interests include social and cultural theory, Marx, kinship and social organization, myth, ritual and narrative, visual anthropology (particularly indigenous video and TV documentary), the body, and the critique of anthropological theory.

E-mail: tst3@cornell.edu.

\section{Note}

1. There are currently many discussions around this theme, running through various anthropo- logical journals. For a previous contribution to the discussion on indigenous rights and anthropological theory in Focaal see Steur (2005).

\section{References}

Hegel, Georg Wilhelm Friedrich. 1953. Introduction. Lectures on the philosophy of history. Trans. R. S. Hartman. New York: Bobbs-Merrill.

Pinkoski, Marc, and Michael Asch. 2004. Anthropology and indigenous rights in Canada and the United States: Implications in Steward's theoretical project. In Hunter-gatherers in history, archeology, and anthropology, ed. Alan Barnard, 187-200. New York: Berg.

Steur, Luisa. 2005. "On the correct handling of contradictions": liberal-culturalism in indigenous studies. Focaal 46: 169-76.

Turner, Terence. 1993. The role of indigenous peoples in the environmental crisis: The case of the Brazilian Kayapo. Perspectives in Biology and Medicine 36 (3): 526-45.

-1996. An indigenous Amazonian people's struggle for socially equitable and ecologically sustainable production: The Kayapo revolt against extractivism. Journal of Latin American Anthropology 1 (1): 98-121.

1999a. Indigenous and culturalist movements in the contemporary global conjuncture. In Las identidades y las tensiones culturales de modernidad, Francisco F. Del Riego, Marcial G. Portasany, Terence Turner, Josep R. Llobera, Isodoro Moreno, and James W. Fernandez, 53-72. Santiago de Compostela: Federacion de Asociaciones de antropologia del Estado Español.

1999b. Activism, activity theory, and the new cultural politics. In Activity theory and social practice, ed. Seth Chaikin, Marianne Hedegaard, and Uffe Juul Jensen, 114-35. Aarhus: Aarhus University Press.

- 2000. Indigenous rights, environmental protection, and the struggle over forest resources in the Amazon: The case of the Brazilian Kayapo. In Earth, air, fire and water: The humanities and the environment, ed. Jill Conway, Kenneth Keniston, and Leo Marx, 145-69. Boston: University of Massachusetts Press.

. 2002. Shifting the frame from nation-state to global market: Class and social consciousness in the advanced capitalist countries. Social 
analysis: The International Journal of Social and Cultural Analysis 46 (2): 56-80.

-2003. Class projects, social consciousness, and the contradictions of 'globalization'. In Globalization, the state and violence, ed. Jonathan Friedman, 35-66. Walnut Creek, CA: AltaMira Press. - 2004. Anthropological activism, indigenous peoples, and globalization. In Human rights, power and difference: The scholar as activist, ed. Carole Nagengast and Carlos Velez-Ibañez, 193-207. Society for Applied Anthropology. Turner, Terence, and Vanessa Fajans-Turner. 2006. Political innovation and inter-ethnic alliance: Kayapo resistance to the developmentalist state. Anthropology Today 22 (5): 3-10. 